\title{
Czech Youth Summer Camps: More than playing games in na- ture
}

Michal Frainšic, Ivana Turčová, Andrew John Martin

Envigogika 11 (2) -Reviewed articles/ Recenzované články

Publikováno/Published dne 21. 10. 2016

DOI: $\underline{10.14712 / 18023061.518}$

\begin{abstract}
Summer camps for children and youth are organized in different countries around the world. These camps vary in length and also in the sport or outdoor activities framing them. Czech summer camps, tábory, have a long history dating back to the beginning of the 20th century. Neuman, Turčová and Martin (2007) describe the specific cultural development of tábory, summer camps for children and youth in the Czech Republic with an anthropological focus. This current article examines the camp conditions, preparation and the role of camp leaders in the holistic program implementation of the turistika activities and outdoor games for these programs. It presents the findings of a survey of 69 leaders of the four main notfor-profit youth organisations undertaking summer camps in the Czech Republic: ATOM (Association of Touristic Youth Clubs), Junák (scouting), Pionýr, and Liga lesní moudrosti (woodcraft). The findings highlight the important role of the qualified, experienced and intrinsically motivated volunteer leaders who spend the entire preceeding year preparing these two to three week summer camps held in basic conditions. The holistic program design provides a pedagogical scaffolding and then culmination for the group of children, who have played outdoor games in natural settings and taken part in turistika activities throughout the year. The implications of these findings are that the 'summer camp' activities are unique to the Czech Republic and provide opportunities for children to 'experience the natural environment', and can also provide inspiration for the scaffolding and development of outdoor adventures and environmental programs internationally.
\end{abstract}

\section{Keywords}

Summer camps; outdoor programs; outdoor and environmental activities

\begin{abstract}
Abstrakt
Letní tábory pro děti a mladé lidi probíhají v různých zemích světa. Tyto tábory se liší délkou a také svým zaměřením a cílem. České letní tábory mají dlouhou tradici, která sahá na počátek 20. století. Neuman, Turčová a Martin (2007) popsali historický a kulturní vývoj fenoménu dětských letních táborů v České republice. Tento článek mapuje podmínky táborů,
\end{abstract}


zaměřuje se na př́pravu a organizaci programu táborů a roli vedoucích $v$ holistickém programu, který zařazuje turistiku, hry a aktivity $\vee$ prírodě. Dále prezentuje výsledky dotazníkového šetření od 69 vedoucích táborů ze čtyř neziskových organizací pořádajících letní tábory v České republice: ATOM, Junák, Pionýr a Liga lesní moudrosti. Výsledky potvrzují důležitost kvalifikovaných, zkušených a vnitřně motivovaných vedoucích, kteři pracují dobrovolně pro neziskové organizace a připravují celý rok jeden dvou- až tř́íýdenní tábor $v$ jednoduchých podmínkách. Holistický program je pro skupinu dětí a mladých lidí vyvrcholením jejich pravidelných setkávání a aktivit $v$ průběhu roku. Výsledky naznačují, že tyto české letní tábory jsou pro děti a mládež príležitostí pohybovat se a pobývat $v$ prírodě, ale $\mathrm{i} a$ vytvořit si kladný vztah $\mathrm{k}$ př́rodě. České tábory jsou kulturně odlišné a jedinečné a mohou být inspirací pro tvorbu programů v přírodě i v jiných zemích světa.

\section{Klíčová slova}

Letní tábory; pobyt $v$ přírodě; programy $v$ prírodě; aktivity $v$ př́rodě 
Summer camps for children and youth are organized in different countries around the world and camp programs are widely discussed. Many studies focus on evaluation of programs using elements of adventure and experiential learning, or environmental education and their effects on personal development. In the USA organised camp programs are a type of recreation program that has focused on youth development in various ways for 150 years (Henderson, Powell, \& Scalin, 2005). Researchers (Bialeschki, Younger, Henderson, Ewing, \& Cassey, 2002) have documented the benefits of organized camp experiences. Camps are organised by organisations such as park and recreation agencies, not-for-profit youth groups, churches, and resident and day camps. In Britain outdoor centres like Brathay Hall Trust or Outward Bound offer young people residential experience. Hickerson and Henderson (2014) argue that youth summer camps in the USA bring most children an enjoyable experience, have the potential to provide ample opportunities for physical activity during the summer months, and bring several positive developmental outcomes (Bialeschki, Henderson, \& James, 2007). These developmental outcomes include environmental awareness, positive identity, positive values, cognitive and physical skill building, social relationships with peers and adults, and physical and psychological safety (Henderson et al., 2005).

Offering programs such as camp experiences, however, does not automatically result in the achievement of intended outcomes. Linkage between program elements and desired outcomes are needed (Baldwin, Caldwell, \& Witt, 2000). Moreover, Martin, Cashel, Wagstaff and Breunig (2006) argue that the success of outdoor adventure program (courses, camps) is connected with the facilitation of the leader (instructor), his/her enthusiasm and motivation for the activity. Similarly, Allen-Craig and Miller (2007) argue that outdoor educators can influence achieving program outcomes. Outdoor educators who wish to focus on specific outcomes may have a greater chance of achieving their desired outcomes with effective staff training and program delivery.

\section{Czech summer camps, Tábory}

The purpose of this paper is to examine the conditions, program content and leadership of summer camps for children and young people developed in the Czech Republic. The programs use a more holistic approach than traditional physical activity based outdoor adventure courses (Martin, Franc \& Zounková, 2004). The theoretical framework is based on a method of course design involving dramaturgy, which is characterized by the intertwining of a variety of social, physical, creative, and reflective/emotional games and activities in nature (Martin, 2001, 2011). The tradition of Czech summer camps is based on the voluntary work of instructors who devote their free time, normally unpaid, to work with a group of children (often about 30) throughout the year in preparation for the annual summer camp. These camps, tábory, have a long history dating back to the beginning of the 20th century. Neuman et al. (2007) describe an anthropological focus on the specific cultural development of tábory, summer camps for children and youth in the Czech Republic. The camps have developed their own indigenous holistic focus on being in nature, involving turistika activities mainly originating in Czech, which have the basics of activity and sport but are mainly about aesthetic, creative, cultural and other educational experiences, whilst moving and playing games in nature (Martin, Turcová \& Neuman, 2016).

Children and youth summer camps are organized by many not-for-profit youth organisations, sport clubs or commercial institutions. These camps were started at the beginning of the 20th century by organisations such as Sokol, Junák (scouting) and Woodcraft. Camp facilities still involve building basic temporary wooden based tents or teepees, close to a forest, on a plain meadow, and by a stream. The simple conditions in which camps are 
organized have recently been more closely scrutinised following European Union health and safety guidelines, which are becoming stricter.

The most common program content for these summer camps are outdoor activities, especially games in nature (Bartůnĕk \& Martin, 2007; Neuman, 2004), turistika activities, creative arts, environmental activities, and also different competitions. The summer camp is often the culmination of regular whole year work with the children within these organisations. The leaders are mainly volunteers who have experienced the camps themselves and have grown up within these organisations. It should be pointed out that there are also other commercial organisations who organise mostly much bigger camps with many more children participating (up to a 100). These camps often have a different form and are not based close to nature; some are focused on a sport, like basketball, football, ice-hockey, volleyball, tennis, etc., or an outdoor pursuit like canoeing, cycling, horse-back riding, or it can be art and drama activities, music, languages, etc.

This current article presents the findings of a survey of 69 leaders from the four main not-for-profit youth organisations undertaking summer camps in the Czech Republic: ATOM (Association of Touristic Youth Clubs), Junák (scouting), Pionýr (skills, knowledge and adventure in nature), and Liga lesní moudrosti (woodcraft). The aim of the research was to examine the range of activities undertaken during the camp, but also the whole year preparation work and scaffolding of learning activities for these groups (Vygotsky, 1978), leading up to their own youth camps that they organize during the summer holidays.

\section{Junák (Scouts)}

The Czech founder of scouting, the secondary school teacher A. B. Svojsík, brought the ideas of English Scouting and American Woodcraft to the Czech lands and managed to involve major scientists and politicians in its formation. He adjusted scouting to Czech conditions, by finding motivation in Czech history and in 1911 he founded the organisation Junák (a Slavic title). His book 'Základy Junáctvi' (The foundations of Scouting; Svojsík 1912) is a key work for that time (Neuman et al., 2007). In the past Junák put great emphasis on learning skills and knowledge (e.g. knots, botanical names, Morse code, etc.), however today Czech scouts have moved towards developing more practical skills, involving problem solving tasks and team work (Šantora, 2008). Junák, the Czech Union of Boy and Girl Scouts, still attracts many young people and today registers over 50000 children, youth and adult volunteers in more than 1600 youth and 400 adult groups. It is the biggest youth educational organisation in the Czech Republic organizing over 1000 summer camps annually (Junák, 2015).

\section{Woodcraft}

Liga lesní moudrosti (League of Forest Wisdom) is an independent organisation of boys and girls, men and women of all ages who have an interest in the 'woodcraft' movement, which was started at the beginning of 20th century by the American writer, painter, scientist and educator Ernest Thompson Seton (Liga lesní moudrosti, 2015). The books and ideas of E. T. Seton and his Woodcraft Indians were also translated and adjusted for the Czech context by another secondary school teacher of natural science, translator and writer Miloš Seifert (1887-1941). Seton's and Seifert's ideas of Woodcraft are still alive today in Czech and focus on leading a simple life in nature. This movement influenced summer camps by providing understanding of the beauty of nature, the camp fire, staying in nature in basic Indian Teepees, and interest in the native people from different parts of the world, especially North America in the ways of rituals, songs, clothing, and games (Neuman et al., 2007). Most activities are realized in children's 'tribes' led by an adult tribe leader. There are also 
tribes of young people, adults or individuals and families with small children (Kubát \& Porsch, 2007). Today woodcraft organisations have registered some 50 tribes with more than 1000 members organising 30 summer camps annually (Liga lesní moudrosti, 2015).

\section{Pionýr}

The Pionýr organisation was created under the organisation Český svaz mládeže (Union of Czech youth) - PO ČSM in 1948 and in 1970 was restructured under the Socialistický svaz mládeže - PO SSM (Socialist Union of Youth). It was a significant organisation in the 1970s and 1980s (Pionýr, 2015). It served under the strong influence of the socialist regime to direct children and youth's free time and to promote communist ideas. When the scout movement was banned and its structure destroyed in 1948 and again in 1969, Pionýr took over scout groups. Fortunately, many scout leaders carried on their work, albeit under a different name, and scout ideas and goals stayed alive. Today Pionýr is still a strong organisation with over 14000 members, undertaking similar work as Junák, but without the previous socialist input (Neuman et al., 2007). Today there are some 650 groups registered, organizing 400 summer camps for 16500 children annually (Pionýr, 2015).

\section{ATOM}

Asociace turistických oddilư mládeže (the Association of Touristic Youth Groups) is the youngest organisation out of the four described, founded in 1991. From 1966 they were Turistické oddily mládeže - TOM (Touristic youth groups), under the Svaz turistiky (Turistika Union), and involved children and youth undertaking Czech turistika and camping activities. Before 1989 TOM groups were the only alternative to Pionýrská organizace mládeže SSM (Pionýr organisation of the Socialist union of Youth) and many scout and woodcraft groups were hidden under TOM between 1970-1989 (Nováček, 2009). Today, they have group meetings during the year and organise many trips both in the Czech Republic and abroad. In summer they also organise camps, canoeing or hiking in mountains. ATOM supports the ideology of a civil society, patriotism, active citizenship, and the democratic traditions of the Czech Republic. The organisation is interconnected with the historical organisation Turistický club (Klub českých turistü, - the official title of the Club of Czech Tourists founded in 1888. ATOM today has some 250 groups and 8000 members and they are called 'Tomíci', organising 200 summer camps (ATOM, 2015).

\section{Method}

This current 'descriptive explorative study' (Thomas \& Nelson, 1996) examined data collected by a questionnaire survey, which reviewed existing conditions and population attributes, as advocated byBurns (2000) and Cohen, Manion and Morrison(2000). The sample consisted of 69 group leaders (19 ATOM, 11 Junák, 26 Pionýr, \& 13 Woodcraft; 35 men \& 34 women) from the four main Czech not-for-profit organisations, which have had a long tradition organising summer camps for children and youth. $39 \%$ of respondents were older than $45,26 \%$ were aged between 30 and 45 , and $35 \%$ were between 19 and $29.77 \%$ of the leaders had more than 6 years' organisation and camp experience. Almost one third of the youth groups, which participated in the research were founded more than 45 years ago, the oldest two were founded in 1913 and 1921, respectively.

The questionnaire consisted of 32 open and closed questions, which focused on the annual camp purpose, place, activities, games and equipment, organisational principles, and also about the whole year work of groups. The leaders' were also asked about their education and qualifications, what was their motivation for leading the children and young people, and how they prepared the summer camp during the year. The questionnaire was created 
by the authors for the purpose of this study and is available in Czech from the authors. Its summary in English is in Appendix 1.

Quantitative data were analysed by the Click4survey software. Qualitative content analysis (Cohen et al., 2000) organized, sorted, and compared this data according to themes (categories). The categories have been coded and further analysed by continuous comparison and analytical induction. Whilst, contexts, situations, events, conditions and interactions cannot be replicated to a wider context than the one studied (Burns, 2000), the credibility is high due to the rich and subjective data. Critics of qualitative research may question its limitations of reliability and validity. However, the most important test of any qualitative study is its quality and this can be attained by considered concepts such as credibility, dependability, and confirmability (Lincoln \& Guba, 1985). It is our contention that the research meets these criteria. It is hoped that the findings can be transferred from one setting to another rather than from a sample to a population, as in a positivist approach (Hussey \& Hussey, 1997).

\section{Results and Discussion}

Czech summer camps for children aged seven and above are organised in July and August during school holidays and last usually two or three weeks (Neuman et al., 2007). The current findings indicated that $84 \%$ of groups organise an annual camp of two (59\%) or of three week length ( $20 \%$ ) during the summer holidays. Almost $90 \%$ of the camps are organized always in the same place. Martin, Dench and Paku (2016) argued that there is a tendency to shorten programs, with Outward Bound programs internationally now averaging about 4 days, in contrast to the traditional 2-3 week courses. Higgins and Nicol (2002) suggested that the optimum time for residential programs is 4 days though longer is generally better.

Children stay in very simple conditions, usually building wood based tents, sometimes also teepees, or simple wooden huts, gathered round a campfire. Some camps cook only on a wood fire and children wash in a stream or lake (Neuman et al., 2007). The current study confirms that $41 \%$ of camps have a bathroom only with cold water and $35 \%$ of participants wash themselves in a stream. $86 \%$ of camps have only dry toilets, $65 \%$ cook for themselves and $73 \%$ do not have a brick kitchen. Children in summer camps sleep mainly in wood based tents (58\%) or in Indian tee-pees ( $29 \%$ ). A third of groups have among their members' children with special needs or handicap.

The most common program content of summer camps are outdoor activities, especially games in nature (Bartůnĕk \& Martin, 2007; Neuman, 2004), turistika activities, creative arts, environmental activities, and also different competitions. Results from the questionnaire involving outdoor organisation leaders indicate that during the year group leaders organise mainly outdoor games and indoor games in their clubrooms (94\%), trips into nature $(86 \%)$ and learning activities about nature - environmental activities $(81 \%)$. The organized summer camps are focused mostly on camping and stays in nature (86 \%), learning about nature $(68 \%)$ and turistika $(57 \%)$ or sport activities (36\%).

According to Neuman et al. (2007) there is often a whole camp game with a certain theme/topic that runs during the camp, for example fairy tales, Indians, Ancient Egypt, the Incas Empire, Greek history, legends from other countries, periods of Czech history, etc. The current findings indicate that more than half of the leaders integrate a whole camp game as a fundamental of everyday work and one fifth of the leaders include it once every two days. Finding the right and attractive topic for the camp game is the hardest job. What is 
never missing on such a summer camp is creativity, involving art, music and drama (Neuman et al., 2007). Motivation for the games is provided by instructors reading a story from a book (75\%), gaining points or other awards ( $74 \%)$, drama or play $(68 \%)$ or a song (23 $\%$ leaders). Jaroslav Foglar (1907-1999), through his work as a long term scouting leader and writer, is recognized as having influenced through his stories of adventure at least three generation's relationship to nature, camping, and scouting story telling (Jirásek, Martin, \& Turčová, 2009. Chour (2000) mentions key points for creating whole camp games. It can be a gripping story (connecting theme, topic), a surprise or secret. Motivational elements to create the atmosphere can involve all five senses, as advocated by Comenius (1632/1907).

$87 \%$ respondents state that their organization requires leaders had a professional qualification for leading youth groups and $97 \%$ require a professional organization for organising summer camps. Organizations have Ministry of Education accreditation for awarding these qualifications, which is a legal condition for youth work. More than three quarters also use other professional qualifications awarded by other institutions. Group leaders are mainly motivated for the team of colleagues they work with, working with children (74\%). Many grew up in the group/organisation and cannot imagine their life without it (61\%). None of respondents are motivated by money, which is to be expected because of the volunteer work ethic of not-for-profit organisations.

The study's focus was on not-for-profit organisations. A third of the leaders mentioned the cheaper prices and lower expenses, as a point of difference from more commercial organisations, because all the leaders work voluntarily without any financial award.

"The big difference is financial, summer camps are more accessible for children from socially weak families."

Moreover, half of respondents noted it is their intrinsic motivation which dominates over extrinsic rewards. According to Lokšová and Lokša (1999), this volunteer behaviour is often more spontaneous, creative and flexible.

"The main award is not money, but great experiences!"

"The award for us is that both children and leaders enjoy the camp."

Children often have many duties during each day. They have to tidy their tent or hut, but also they help in the kitchen with meals or dishes, go shopping and to the post office, have to collect and chop wood for the fire, and 'guard' the camp during both the day and night, etc. (Neuman et al., 2007). Two-thirds (46) of respondents think that camps organized by not-for-profit organizations are more beneficial for the children's lives because they are included into the everyday camp duties, which encourages self-reliance and self-confidence.

According to Neill's (2008) findings there are seven course factors that affect the outcomes of outdoor adventure education programs: The learner, their motivation, structure of personality and previous experiences; the environment, forest, mountains, water, weather and place; the activity, its type and difficulty; program, its focus, goal, content, approaches, methods; the group or social environment, state of a group, prevailing ways of behaviour, atmosphere; the leader or facilitator, leadership styles, values hierarchy, knowledge and skills, relationship to participants; the cultural influences, traditions, norms, habits, religion.

In this current study, the following five themes emerged from the content analysis of respondents' answers related to the most important principles for successfully organizing a 
summer camp. Those were the leader, safety principles and legislations, the place, program, and group. The leader or a group of leaders/instructors was stressed by respondents as the most important factor, which contrasts to Neill's (2008) findings above which ranked this factor sixth.

"[...] to have a group of good, responsible, experienced and qualified instructors is a key thing for the summer camp. They should be enthusiastic, friendly and organized."

The program is not only prepared and delivered by leaders, but also by the children, who participate on its creation during the year in their weekly meetings and its operation during the camp.

"The children help with the camp running (build tents, cook...,), therefore they are more responsible for themselves, friends, and their things."

The group or social environment, which is represented by a group of (30-40) children who have known each other for at least a year also has a strong effect on successful camp operation. The leaders reinforced this fact, which distinguishes summer camps organized by not-for-profit rather than commercial organizations. At commercial camps both children and leaders meet each other at the camp for the first time.

"Our camps are more familiar; leaders, children and parents know each other. Leaders know children's social background, trust each other. We have less children, closer relationships, deeper experiences; we can better adjust to the individual needs of participants.

In a group of children who know each other for a year, you can better build social relationships and you can better influence their education.

A bigger emphasis is put on friendship and other values. Knowing each other has advantages. You don't have to introduce each other, everyone is a friend since the camp beginning. We can go deeper, to the camp essence, friendship, children's stay in nature."

"The programme is developed through the whole year for a group of children we know, therefore it of a higher quality."

"Our programmes are more educational. The commercial camps often offer trendy activities, which are 'cool' or 'in', but without any educational effect."

"Our programmes are more holistic, emphasizing moral development of children."

\section{Conclusions}

The array of commercial and not-for-profit summer camps for children and young people is very broad in the Czech Republic. It is noted that future research could also compare non-profit organisation with profit organisation. This current study surveyed the four biggest not-for-profit youth organizations organizing summer camps, which involve two to three week stays close to nature. Almost all these not-for-profit organisations still work on a voluntary principle. Leaders work with the children regularly during the whole year without any financial award. The basic facilities and place where the summer camps takes part is 
often the same as it was 30 or 50 years ago, usually a plain meadow by a stream and close to woods. Despite today's modern equipment and technologies, simple wooden-based tents or teepees are still built. All camp living conditions are kept at a basic level close to nature. The children's living environment during the camp is not made more comfortable by modern equipment and technologies like computers, smart phones, etc. The whole camp games/themes connecting all program parts are irreplaceable elements of every camp for all groups. Every activity is realized within the framework of a story or fairy tale, which is acted out by both by leaders and children. The success of activities and the whole program depends on the facilitation skills of the leader and creating a good and reliable staff team.

The findings from these not-for profit camps highlight the importance of the qualified, experienced and intrinsically motivated volunteer leaders who prepare year-long for these two to three week summer camps in basic conditions. The holistic program design provides a pedagogical scaffolding and then culmination for the group of children, who have played games in nature and taken part in turistika activities throughout the year. The implications of these finding are that these summer camps' activities mainly originate in Czech and provide opportunities for children to 'stay in nature', but can also provide inspiration for the scaffolding and development of outdoor adventure and environmental programs internationally.

\section{References}

- Allen-Craig, S., \& Miller, J. (2007). Can outdoor educators make a difference? The effect of outdoor educators on achieving program outcomes. ACHPER Australia Healthy Lifestyles Journal, 54(2), 5-12.

- Asociace TOM (2015): Co je Asociace TOM? Retrieved from http://www.atom.cz/asociace-tom/co-je-asociace-tom/

- Baldwin, C., Caldwell, L., \& Witt, P. (2005) Deliberate programming with logic models: From theory to outcomes. In L. Caldwell \& P. Witt (Eds.), Youth development and recreation services (pp. 219-239). PA: Venture: State College.

- Bartůněk, D., \& Martin, A. J. (2007). Games in nature for young children. Prague: International Young Nature Friends IYNF.

- Bialeschki, M. D., Younger, T., Henderson, K. A., Ewing, D., \& Cassey, M. (2002). Happy but sad. Camping Magazine, 75(1), 38-41.

- Bialeschki, M. D., Henderson, K. A., \& James, P. A. (2007). Camp experiences and developmental outcomes for youth. Child and Adolescent Psychiatric Clinics of North America, 16(4), 769-788. Retrieved from http://linkinghub.elsevier.com/retrieve/pii/S1056499307000594 pmid:17823055 http://dx.doi.org/10.1016/j.chc.2007.05.011

- Burns, R. B. (2000). Introduction to Research Methods. 4th ed. London: Sage.

- Chour, J. (2000). Receptář her: Náměty a návody pro vedoucí dětí a mládeže. Praha: Portál. 
- Cohen, L., Manion, L., \& Morrison, K. (2000). Research methods in Education. 5th ed. London and New York: Routledge/Falmer. Retrieved from http://www.tandfebooks.com/action/showBook?doi $=10.4324 / 9780203224342$ http://dx.doi.org/10.4324/9780203224342

- Comenius, J. E. (1632). The great didactic of John Amos Comenius/translated into English and edited with biographical, historical and critical introductions by M.W. Keatinge (2nd ed.). London: Black.

- Henderson, K. A., Powell, G. M., \& Scanlin, M. M. (2005). Observing Outcomes in Youth Development: An Analysis of Mixed Methods. Journal of Park and Recreation Administration, 23(4), 58-77. Retrieved from https://www.researchgate.net/profile/Karla_Henderson/publication/228496972_Observing_Outcomes_in_Youth_Development An Analysis of Mixed Methods/links/00b7d52b20cc433124000000.pdf

- Hickerson, B. D. \& Henderson, K. A. (2014). Opportunities for Promoting Youth Physical Activity: An Examination of Youth Summer Camps. Journal of Physical Activity and Health, 11(1), 199-205. Retrieved from http://journals. humankinetics.com/doi/10.1123/jpah.2011-0263 pmid:23359209 http://dx.doi.org/10.1123/jpah.2011-0263

- Higgins, P., \& Nicol, R. (2002). Learning as Adventure: Theory for Practice. The Summer Activities for 16 Year-Old Scheme. Edinburgh: DfES and Connexions Service.

- Hussey, J., \& Hussey, R. (1997). Business research. London: MacMillan Press. Retrieved from http://link.springer.com/10.1007/978-1-349-25262-6 http://dx.doi.org/10.1007/978-1-349-25262-6

- Jirásek, I., Martin, A. J., \& Turčová, I. (2009). A symbol of games and play: Jaroslav Foglar's influence on Czech education in nature. Horizons, 2009(45), 28-32.

- Junák (2015). Junák - svaz skautů a skautek ČR, 1, Retrieved from http://www.skaut.cz/skauting/o-skautingu/

- Kubát, V., \& Porsch, J. (2007). Liga lesní moudrosti. Gymnasion, 8(2), 81-84.

- Liga lesní moudrosti, (2015). Liga lesní moudrosti. . Retrieved from http://www.ligalesnimoudrosti.cz/cs/o-nas/

- Lokšová, I., \& Lokša, J. (1999). Pozornost, motivace, relaxace a tvořivost dětí ve škole: Teoretická východiska a praktické postupy, hry a cvičení. Praha: Portál.

- Martin, A. J. (2011). The dramaturgy approach to education in nature. Journal of Adventure Education and Outdoor Leadership, 11(1), 67-82. Retrieved from http://www.tandfonline.com/doi/abs/10.1080/14729679.2011.575691 http://dx.doi.org/10.1080/14729679.2011.575691

- Martin, A. J. (2001). Dramaturgy: An holistic approach to outdoor education. Australian Journal of Outdoor Education, 5(2), 34-41.

- Martin, A. J., Dench, S., \& Paku, L. (2016). An exploration of Outward Bound New Zealand's organizational culture: 1962-2012. Journal of Adventure Education and 
Outdoor Learning. doi, 10(1080), 1472-9679. Retrieved from http://www.tandfonline.com/doi/full/10.1080/14729679.2015.1122540 http://dx.doi.org/10.1080/14729679.2015.1122540

- Martin, A. J., Franc, D., \& Zounková, D. (2004). Outdoor and experiential learning. Aldershot, UK: Gower.

- Martin, A. J., Turčová, I., \& Neuman, J. (2016) Turistika activities and games, dramaturgy and the Czech outdoor experience. In B. Humberstone, H. Prince, \& K. Henderson (Eds.), International Handbook of Outdoor Studies (pp. 197-306). London: Routledge.

- Martin, B., Cashel, C., Wagstaff, M., \& Breuning, M. (2006). Outdoor leadership: Theory and practice. Champaign, IL: Human Kinetics.

- Pionýr, (2015). Pionýr - kdo jsme. . Retrieved from http://pionyr.cz/o-pionyru

- Neill, J. (2008). Enhancing life effectiveness: The impact of outdoor education programs. Unpublished PhD thesis. Sydney: University of Western Sydney.. Retrieved from http://wilderdom.com/phd

- Neuman, J. (2004). Education and learning through outdoor activities. Prague: DUHA.

- Neuman, J., Turčová, I., \& Martin, A. (2007). Being in nature, summer camp but not as we know it. Horizons, 40(40), 20-35.

- Nováček, M. (2009). Asociace turistických oddílů mládeže ČR. Gymnasion, 11(1), 97-101.

- Šantora, R. (2008). Sto prvý rok skautingu. Gymnasion, 9(1), 81-85.

- Svojsík, A. B. (1912). Základy Junáctví [The foundations of scouting]. Praha: Junák.

- Thomas, J. R., \& Nelson, J. K. (1996). Research Methods in Physical Activity. Champaign: Kinetics.

- Vygotsky, L. S. (1978). Mind in society. Cambridge, MA: Harvard University Press. 


\section{Appendix 1 Questionnaire}

Your organisation's name:

Foundation of your youth group: date: place:

1. What activities do you do with children during the year (excluding the summer camps) - e.g. cycle-touring, outdoor games, games in a club room, climbing, watertouring (canoeing), turistika, mountaineering, learning about nature, etc.

2. At what age did you become a member of this youth group? How long are you a member of this group?

3. How long are you leading this group?

4. Does your organisation require a licence for organising summer camps and leading a youth group? Do you have any other licences?

5. What is your motivation to be the leader of young people?

6. How many youth leaders are there at your summer camp?

7. Can you describe the system of leaders' participation during the camp programme, including their function.

8. Do you have leaders who take part only in the camp, but do not take part during the whole year activities?

9. How many male and female leaders do you have?

10. How old are your leaders? 15-18, 19-26, 27-50, over 50

11. Did your leaders take part in your camps as children or not?

12. How many of your leaders work and how many study?

13. How old are children in your group? How many in each age group - 6-10, 11-14, 1518 , above 18 ?

14. Can anyone take part in your activities or are they only for group members?

15. Do you have members with special needs or any handicapped?

16. How long is your camp? How many camps do you organise every year?

17. How is your camp equipped? (e.g. washing rooms, toilets, kitchen, accommodation)

18. What sort of camp do you organise? (e.g. cycling, climbing. sport, canoeing, mountaineering, camping, turistika, etc.)

19. Name five most important principles for organising a summer camp.

20. What is your schedule of camp preparations during the year?

21. How much time of the camp is spend on the whole camp game ( 1 or 2 stages every day, 1 stage a day, it is not important, there is no whole camp game)

22. Tick activities which are part of the camp programme (stage games, night games, sport games, creative activities, art activities, manual work, religious activities, educational programme - discussions, workshops, cooking, campfires, rituals, drama, other?)

23. Name five criteria according to which you choose the topic of the whole-camp game.

24. How do you motivate children to be part of stage games? (e.g. roleplay, drama, book reading, song, points, award, we do not motivate, other forms of motivation)

25. What form of motivation is the most favourite among leaders and works best for children? 
26. Does your organisation (youth group) differ from the other groups? If yes, in what way?

27. Do you know about other non-profit youth organisations and their work?

28. What is the difference between summer camps organized by non-profit organisations and summer camps organized by commercial companies? 